\title{
The Impact of Foreign Trade Policy 2015-2020 on Inclusive Growth of India
}

\author{
Dr. Bharati Kiyawat ${ }^{1}$, Shruti Kiyawat ${ }^{2}$ \\ ${ }^{1}$ Assistant Professor, Economics, Govt. K. P. College, Dewas (MP), India \\ ${ }^{2}$ Student pursuing MBA in Foreign Trade, DAVV, Indore, India
}

\begin{abstract}
Foreign Trade Policy or the FTP is the set of guidelines or the procedures which are being formulated by the government to incorporate in the economy and being followed so as to attain maximum amount of Foreign Trade. Due to uneven distribution of natural resources and the theory of comparative cost, some countries are more suitable place to produce some goods more economically than other countries which encourages foreign trade. The new Foreign Trade Policy (2015-20) is made product wise and location wise and tried to maximize the foreign trade from the country keeping in mind Central Government's pet projects, 'Make in India' and 'Digital India' so as to attain export target of 900 billion dollars by year 2020 through newly introduced two schemes. The Policy spells out measures for increased digitalization of exports and imports with the aim to gradually move towards a paperless office in $24 \times 7$ environment and self-certification by established exporters and importers. The export promotion of capital goods scheme (EPCG) is also made lucrative. Incentives are available for SEZs also. These measures will create more employment avenues in manufacturing and services.
\end{abstract}

Keywords: Foreign Trade Policy (2015-20), Merchandise Export from India Scheme, Service Export from India Scheme, Export Promotion of Capital Goods Scheme

\section{Introduction}

Foreign Trade Policy or the FTP is the set of guidelines or the procedures which are being formulated by the government to incorporate in the economy and being followed so as to attain maximum amount of Foreign Trade

Foreign Trade Policy in India is formulated by the Government of India, Ministry of Commerce and Industry, Department of Commerce.

\section{Importance}

Due to uneven distribution of natural resources, some countries are more suitable place to produce some goods more economically than other countries. Further the underdeveloped and developing countries have to depend upon developed countries for financial help, which ultimately encourages foreign trade.

According to the theory of comparative cost, each country should concentrate on the production of those goods and/or services for which it is best suited and specializes in the production of that goods and/or services, thus there is a significant increase in the overall production with minimized costs and resulting in higher standard of living of the people.

Foreign Trade Policy helps in increasing the revenue of a nation by improving on the exports, which in turn help in improving the Balance of Payment. Foreign Trade propels economic growth and national development. The primary purpose is not the mere earning of foreign exchange, but the stimulation of greater economic activity.

\section{Scope \& Objective}

With an aim to make India a significant partner in global trade by 2020 and for increasing global competitiveness of domestic products and aligning India's tariff framework with the long term commitment at World Trade Organisation, the government formulated Foreign Trade Policy (FTP) for the term of 5 years commencing from 2015 .

The new Policy (FTP 2015-20) is made product wise and location wise and tried to maximize the foreign trade from the country

This policy aims at boosting India's exports and Central Government's pet projects, 'Make in India' and 'Digital India' is being integrated with the new FTP 2015-20.

The Policy (FTP 2015-20) of India mainly focuses on an ambitious export target of 900 billion dollars by year 2020 highlights a visible push to 'Make in India'.

The foreign trade policy of India is based on two major objectives, they are as follows:

1) To double the percentage share of global merchandise trade within the next five years.

2) To act as an effective instrument of economic growth by giving a thrust to employment generation.

\section{Schemes Under this Policy}

Two schemes namely; Merchandise Exports from India Scheme (MEIS) and Services Exports from India scheme (SEIS) were introduced under this policy. 


\section{International Journal of Science and Research (IJSR) \\ ISSN (Online): 2319-7064}

Index Copernicus Value (2013): 6.14 | Impact Factor (2014): 5.611

These two schemes replace the gamut of old norms and reward for the exporters on the basis of the importance attached to the exported items and the targeted market.

Objective of Merchandise Exports from India Scheme (MEIS) is to offset infrastructural inefficiencies and associated costs involved in export of goods/products, which are produced / manufactured in India, especially those having high export intensity, employment potential and thereby enhancing India's export competitiveness. The 'Services Exports from India Scheme' (SEIS) is for increasing exports of notified services.

Key Highlights \& FEATURES OF NEW FTP: The Policy spells out measures for increased digitalization of exports and imports with the aim to gradually move towards a paperless office in $24 \times 7$ environment and self-certification by established exporters and importers.

These schemes (MEIS and SEIS) replace multiple schemes earlier in place, each with different conditions for eligibility and usage. Incentives (MEIS \& SEIS) are available for SEZs also. E-Commerce of handicrafts, handlooms, books etc., eligible for benefits of MEIS. SEIS shall apply to 'Service Providers located in India' instead of 'Indian Service Providers'.

The Government has extended tax breaks to exporters of defense, pharma, farm produce and environment-friendly products. The export obligation period for items related to defense, military stores, aerospace and nuclear energy will be 24 months instead of 18 months.

The policy has also reduced the exports obligation for those procuring capital goods domestically to 4.5 times imports as against six times under the export promotion of capital goods scheme (EPCG), which will encourage the domestic capital goods industry, according to analysts. This will help exporters develop production capacities for both local and global consumption.

Manufacturers that are also status holders will be enabled to self certify their manufactured goods as originating from India.

Export of handloom products, books \& periodicals, leather footwear, toys and customized fashion garments through courier or foreign post office for value up to Rs. 25,000 would also be able to get benefit of Merchandise Exports from India Scheme (MEIS)

Duty credit scrips will be freely transferable and usable to facilitate payment of custom duty, excise duty and / or service tax. Debits against scrips would be eligible for CENVAT credit or drawback also. Unlike annual reviews, FTP will be reviewed after two-and-half years for its impact on business climate. Enhanced focus will be placed on export of high value products to traditional market in developing world. Similarly there will be strong emphasis to supply high quality inputs for the manufacturing sector in these markets. Plus, the custom duties applied on inputs for India's manufacturing sector will be fully optimized. The realignment of tariff structure will put India in advantageous position in regional trade pacts being negotiated. So far India was excluded from pacts such as the Trans-Pacifica Partnership (TPP) partly because its tariffs are not competitive. The experts feel the policy will benefit the exporting community, with special focus on services exporters. Simplification of procedures will go a long way in integrating India in the global value chain; improving India's ranking in ease of doing business index and reducing the transaction cost in international trade. E-Commerce sector stands to gain from the FTP. Intensive focus on higher value additions and technology infusion, quality and standards will lead to zero defect products. Lower tariffs on inputs and raw material will have a cascading impact on the economy.

Measures are adopted to nudge procurement of capital goods from indigenous makers under the EPCG scheme by reducing specific export obligation to seventy fifth i.e. 4.5 times imports as against six times of the normal export obligation. This will promote the domestic capital goods producing industry.

These measures will create more employment avenues in manufacturing and services.

In order to provide a boost to exports from Special Economic Zones (SEZs), Government has currently decided to extend benefits of both the reward schemes (MEIS and SEIS) to units situated in SEZs.

Trade facilitation and enhancing the ease of doing business are the other major focus areas in this new FTP. One of the major objectives of new FTP is to move towards paperless working in $24 \times 7$ environment.

Recently, the government has reduced the number of necessary documents needed for exports and imports to three, which is comparable with international benchmarks. Now, a facility has been created to upload documents in exporter/importer profile and the exporters won't be required to submit documents repeatedly.

Government has also simplified numerous Aayat Niryat Forms, bringing in clarity in different provisions, removing ambiguities and enhancing electronic governance.

Manufacturers will currently be enabled to self certify their factory-made goods in phases, as originating from India with a view to qualifying for preferential treatment under numerous forms of bilateral and regional trade agreements.

This new System will help these manufacturer exporters considerably in getting quick access to international markets.

A number of steps are introduced for encouraging manufacturing and exports. The steps include a quick track clearance facility for these units, permitting them to share infrastructure facilities, allowing inter unit transfer of goods and services, permitting them to set up warehouses near the port of export and to use duty free equipment for training purposes.

Nomenclature of Export House, Star Export House, Trading House, Premier Trading House certificate changed to 1,2,3,4,5 Star Export House. 


\section{International Journal of Science and Research (IJSR) \\ ISSN (Online): 2319-7064}

Index Copernicus Value (2013): 6.14 | Impact Factor (2014): 5.611

The criteria for export performance for recognition of status holder have been changed from Rupees to US dollar earnings.

Reduced Export Obligation (EO) (75\%) for domestic procurement under EPCG scheme.

Online procedure to upload digitally signed document by Chartered Accountant/Company Secretary/Cost Accountant to be developed.

Inter-ministerial consultations to be held online for issue of various licenses.

No need to repeatedly submit physical copies of documents available on Exporter Importer Profile. Validity period of SCOMET export authorization extended from present 12 months to 24 months. The government is pitching India as a friendly destination for manufacturing and exporting goods, and the new policy is being seen as an important step towards realizing that goal.

Branding campaigns planned to promote exports in sectors where India has traditional Strength.

Entitlement under MEIS: Exports of notified goods/products with Indian Trade Clarification (Harmonized System) $\{$ ITC $[\mathrm{HS}]\}$ code, to notified markets as listed in Appendix 3B, shall be rewarded under MEIS. Appendix 3B also lists the rate(s) of rewards on various notified products [ITC (HS) code wise]. The basis of calculation of reward would be on realized FOB value of exports in free foreign exchange, or on FOB value of exports as given in the Shipping Bills in free foreign exchange, whichever is less, unless otherwise specified.

Export of goods through courier or foreign post offices using e-Commerce

1) Exports of goods through courier or foreign post office using e-commerce, as notified in Appendix $3 \mathrm{C}$, of FOB value up to Rs. 25000 per consignment shall be entitled for rewards under MEIS.

2) If the value of exports using e-commerce platform is more than Rs 25000 per consignment then MEIS reward would be limited to FOB value of Rs. 25000 only.

3) Such goods can be exported in manual mode through Foreign Post Offices at New Delhi, Mumbai and Chennai.

4) Export of such goods under Courier Regulations shall be allowed manually on pilot basis through Airports at Delhi,

Mumbai and Chennai as per appropriate amendments in regulations to be made by Department of Revenue. Department of Revenue shall fast track the implementation of EDI mode at courier terminals.

The following exports categories /sectors shall be ineligible for Duty Credit Scrip entitlement under MEIS, EXIM Policy 2015-20 (FTP 2015-20).

1) EOUs / EHTPs / BTPs/ STPs who are availing direct tax benefits / exemption.

2) Supplies made from DTA units to SEZ units
3) Export of imported goods covered under paragraph 2.46 of FTP;

4) Exports through trans-shipment, meaning thereby exports that are originating in third country but transshipped through India;

Deemed Exports;

5) SEZ/EOU/EHTP/BPT/FTWZ products exported through DTA units;

6) Items, which are restricted or prohibited for export under Schedule-2 of Export Policy in ITC (HS), unless specifically notified in Appendix 3B.

Service Export.

7) Red sanders and beach sand.

8) Export products which are subject to Minimum export price or export duty.

9) Diamond Gold, Silver, Platinum, other precious metal in any form including plain and studded jewellery and other precious and semi-precious stones.

10) Ores and concentrates of all types and in all formations.

11) Cereals of all types.

12) Sugar of all types and all forms.

13) Crude/petroleum oil and crude/primary and base products of all types and all formulations.

14) Export of milk and milk products.

15) Export of Meat and Meat Products.

16) Products wherein precious metal/diamond are used or Articles which are studded with precious stones.

17) Exports made by units in FTWZ.

\section{Comments}

The Interest Subvention Scheme for the export sector should be announced immediately so that a stable framework both of the Foreign Trade Policy and credit support is available to the exporters to do their costing for fetching new orders in the competitive international market.

The Policy, though, seems to focus a lot on easing the processes but still this policy puts certain bottlenecks in the manufacturing sector in India. The MEIS, for example, is a new scheme that is aimed and boosting exports but of specified goods to specified markets and SEIS is for increasing services exports of notified services.

The markets are yet not free and the government's this Policy is still trying to keep itself entrenched as a conduit between Indian exporters and their markets.

\section{References}

[1] http://indiantradeportal.in, $\mathrm{http}: / /$ articles.economictimes.indiatimes.com, http://www.slideshare.net,

[2] http://www.yourarticlelibrary.com, 